\title{
Bringing a myriad of gifts: June Kendrick
}

\author{
Barbara Staniforth and Mary Nash
}

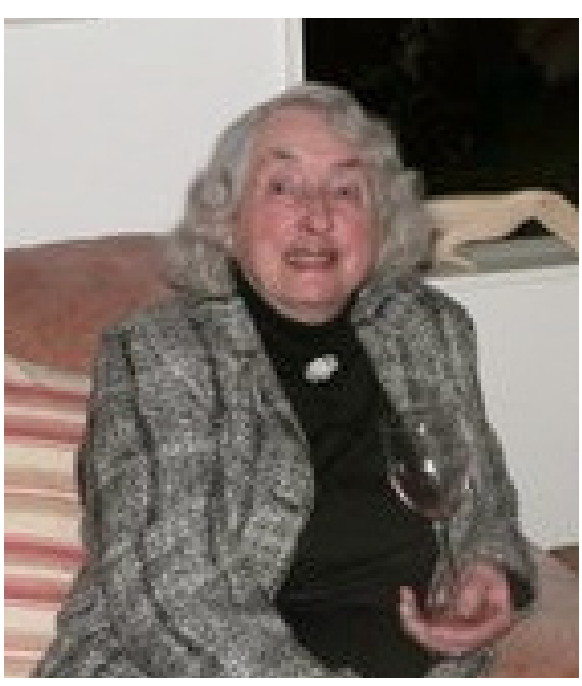

This article portrays the life and work of June Kendrick, a life member of the ANZASW, who has, and continues to have, a passion for social justice, social work education and social work with older people. The authors have both interviewed June at different times to collect her life story. We are writing this after spending a couple of sessions together with June, helping her to go through and sort out her extensive archives. This exercise provided us with a material display of the range of her involvement in social policy, practice and education and professionalism in social work. We have followed a chronological approach to writing this account, followed by reflective commentary on some of the key themes representing June's achievements and contributions to social work. Her salient interests have been in social policy, residential work, social justice, the ANZASW, social work education and social work with the older person. June continues to live in her home in Auckland and remains active socially. She is also a keen follower of current social and political events and keeps in regular contact with several social workers with whom she has worked over the years.

\section{Brief biographical details}

June's early childhood was spent during the Depression years in a family which she describes as a 'typical New Zealand kiwi situation'. June is a third generation New Zealander with her father's family coming from England and her mother's from Ireland and England via the USA. June describes them as both being very interesting people and remembered her father always had a keen interest in politics and social issues.

June attended Auckland Girl's Grammar, when the school leaving age was 14. She then went on to attend teacher's college as this was the only way she could study at university.

I actually started off going to teacher's college and university because in my day women's education sort of fitted for one of two things, either teaching, or nursing seemed to be the other one ... One of the reasons that I went to training college was that it enabled me to also go to university ... although the tuition was free there was no living allowance and very little part time work, or women's work that you could actually do to fund yourself (J. Kendrick, personal correspndence, 10/11/1999).

June completed her teacher's certificate, graduating with a BA in English and History from the Auckland College of the University of New Zealand. She completed her MA in History in 1948 and continued to teach History at Northcote College in Auckland in 1949. 


\section{A start in child welfare}

June had had an interest in working for the civil service and had talked to people about careers in the area of child welfare. This included Charlie Peek (Superintendent of Child Welfare) who told her to come back when she had 'a bit more experience under her belt' (at that time one had to be 25 to go into child welfare work). In 1951, June was alerted by the child welfare office in Auckland that there was a vacancy available.

I was very attracted to work with what was in those days the Child Welfare Division, so that in 1951 I took an appointment as a child welfare officer in the Auckland office ... I suppose I gained my practical experience. We were known as child welfare officers ... I don't think we really thought in terms of being social workers as such, as one didn't then (J. Kendrick, personal correspondence, $28 / 07 / 06$ ).

June describes the decision to leave teaching to go into child welfare with the accompanying salary drop that would occur. At that time June was one of the few child welfare officers to come from a teaching background, with the others coming mainly from nursing backgrounds.

When I joined child welfare back in 1951, there were about eight women officers and eight men officers, and we did the whole of Auckland, from Auckland, up as far as Wellsford in the north and down to Te Kauwhata in the south, but ... remember [the population of] Auckland was, I think about 250,000, or 200,000 people at that stage, and so it was a good deal smaller (J. Kendrick, personal correspondence, 28/07/06).

June describes caseloads as being significantly smaller then. She explained how strong community contacts were at that time. For example, the visiting social worker would always call on the local school teacher, the local vicar and in due course, the Māori Women's Welfare League. A good part of June's job at that time involved the 'tracking' of children who had been born out of wedlock. June describes the 1927 amendment to the Child Welfare Act, which stipulated that all children born out of wedlock needed to be tracked by the child welfare officer, called the E527s. June explained that this was work that no one wanted to do as it was embarrassing and felt intrusive.

June describes the role of the woman officer:

We did, of course, all the babies, and boys up until the age of 10 I think. That was about it, and that would have included those in foster homes (J. Kendrick, personal correspondence, 10/11/1999).

\section{Victoria programme 1953-1954}

As a graduate, June was selected to study for the Diploma in Social Science at Victoria University of Wellington, which gave her a professional qualification in social work.

I wasn't there very long [Child Welfare] before there was a certain amount of pressure to apply for a bursary to go to the Victoria School and partly because it was perhaps unusual that I had quite a strong academic background and I suppose that wasn't the tendency. There were very few university graduates coming into the work at that stage (J. Kendrick, personal correspondence, 10/11/1999). 
June describes how this opportunity also involved being bonded to the Government for a five-year period following graduation and that for many people considering study, this may have been a disincentive for training:

We got my full salary for the full two years which was good, but the five years afterwards, that was the one that made you really stop and think because it really stopped you doing anything much. We found out that marriage didn't necessarily wipe that obligation but of course if you had children it did because at the time no law would have separated a mother from her child. Remember that was another time when the greatest job any woman was expected to do was to stay home and look after her children ... I think we felt we didn't have any choice if we had children but to stay home and look after them, because not to opened up all these terrible possibilities of deprived children, so that anyway ... I think I'd decided by that stage to let things take their course, so I did the two years (J. Kendrick, personal correspondence, 10/11/1999).

June was part of the 1953-1954 intake and describes herself both as a Marshian and a Minion (McCreary, 1971a, b) having been taught both by Professor David Marsh and Professor Bill Minn. Since the former put a stress on policy and the latter emphasised therapeutic work, June reflected their respective influences in her career. June also describes significant contributions made by John McCreary and Jim Robb as well as by Jean Robertson, who had earlier taught social work in Australia and went on to develop social work courses in Singapore.

June had had an initial interest in probation work so did a work placement at Arohata and then with Probation. June describes having 'lost' one of her 'probationers' who absconded early on. This may partly have influenced June's decision to move into the mental health field and do her last placement in Dunedin in 1954 with Professor Ironside at Dunedin hospital.

\section{A stint in mental health}

After graduation, June moved to Auckland and went to work with Janet Bogle (who later became Janet McGeorge), who had started as the first psychiatric social worker at what was then known as the Auckland Mental Hospital Carrington. At that time there were approximately 1,100 patients for the two social workers to attend to. June makes reference to the difficulties of working in such an environment, particularly in relation to the lack of status of social work at the time:

The doctors only saw you as this sort of ... the 'doers' of the ward and you know, you were the ones who ran out and found where somebody had left their teeth or their glasses or something like that, that sort of role (J. Kendrick, personal correspondence, 28/07/06).

\section{Back to Child Welfare}

Having always planned to return to child welfare, and wanting to try living in a rural setting, June went back to Child Welfare at the Taumarunui office after it was opened in 1955.

It was a promotion I guess in terms of status ... anyway there were two of us, myself and one male officer (Sid Hallett) and we did the whole district round National Park, over to Taupo ... (J. Kendrick, personal correspondence, 28/07/06).

Having been trained in social work, and having previous child welfare experience, June was highly sought after, and soon was promoted a grade and moved to the Masterton office 
where she worked with Brian Manchester. Reminiscing on this period, when he and June would share the office car for visiting remote areas in the Wairarapa, Brian describes June (then a senior child welfare officer) as an unfailing source of sound information regarding work with adoption cases, practices and issues, saying she was very experienced and thought deeply about her work (Manchester, 2008, p 82).

The tradition of the time was that male child welfare officers were responsible for boys 10 years and over, and young males up to seventeen, and to the customary discharge age of about 18 years for State Wards. Women officers were responsible for boys under 10 years and girls of all ages under 17 or later discharge in the case of State Wards.

The consequence of this division of work was that I was not administratively required to report to June about any work that I undertook. However, for men's cases I was allocated the northern sector of the Wairarapa. June also operated in this sector for women's work. The office had only one car. There was some provision for officers to use their own cars on mileage allowance though this always seemed a somewhat grudging allocation, preferably to be used for local emergencies. The consequence of all this was that apart from cases requiring more immediate attention, June and I accumulated work and made joint two-day visits, about every four weeks, to the north Wairarapa, leaving about 8.30 a.m. on the first day and after staying overnight in Dannevirke or Pongaroa worked our way back to Masterton on the second day to finish about 10.00 p.m. They were long, hard days with much driving on unsealed roads and locating people in remote locations. The bonus for me, at such an early stage of my career, was that in the course of hours of road travel we were able to discuss cases in which we were separately and quite often jointly involved. June was certainly innovative, thoughtful and really enthusiastic about her work (B. Manchester, personal correspondence, 31/01/2011).

In his own memoirs of working in the Wairarapa as a child welfare officer, Brian recounts how he and June worked efficiently together with a destitute family so that by the end of the day, they had arranged a job for the father, a home, clothing and transport to get them to their new house, with basic furniture already organised. He comments that:

In an era when social workers were being saturated with literature about client self-determination and non-directive counselling, we felt obliged to feel some token shame at taking over people in this way (Manchester, 2008, p 82).

Here, Brian may be recalling one of the leading text books on the casework relationship (Biestek, 1957), with which he and June would have become very familiar. Years later, Biestek wrote a history of the 'elusive and very complicated concept' of client self-determination which illustrated the complexity of the social worker's attempt to work with the client on the client's own behalf, while also carrying out agency functions which may well be in conflict (Biestek, 1978, p. 5).

June was married in 1958 and this took her back to Auckland to live. She moved back to the Auckland Child Welfare office but soon became pregnant. June explained that it was highly unusual for a pregnant woman to be working in a Child Welfare office at the time and that the staff were quite protective of her and that the office had a very 'family' sort of feel.

It was very interesting. I actually had a certain personal conflict too. I felt very guilty interviewing people who were presenting for adoption because we did a lot of adoption work and I was actually... because of my condition, they weren't very keen on having an obviously pregnant 
woman, I think, visiting various clients, and so I was found a rather nice desk job which would involve a lot of desk work, handling what we knew as the Infant Life Protection Section, which was known as the ILP Section, so you had a lot of sort of clerical work, keeping track of people ... (J. Kendrick, personal correspondence, 28/07/06).

\section{An Association is formed}

In the early 1960s June was living in Auckland with two children. A group of women who had attended the Victoria Programme (including Judith MacKenzie and Janet McGeorge) met together periodically through that time. At one point Professor Minn was visiting Auckland and met with a group of graduates. June describes in brief her part in the process of the establishment of the Social Work Association:

I initially thought of forming a sort of 'old students' thing from Victoria, but it actually was Professor Minn who I recall very clearly, made the point that he felt it should be a social workers association and ... you know, he was obviously quite right. We formed an association in Auckland in 1962 and we just rang around all the groups we knew who had social workers. It was an interesting group of people, a lot of people from the voluntary sector, and we got going. That was when I realised a person I had known briefly, because we had been at Auckland University at one stage, was Merv Hancock. Merv was in Dunedin and we were in Auckland and I found from Merv that they had done the same thing in Dunedin spontaneously and something similar in Wellington too. Dunedin organised a study conference in '62 and ... by '64 of course we had our inaugural conference and the rest is history (J. Kendrick, personal correspondence, 28/07/06).

The inaugural conference in 1964 was held in Auckland. June describes her involvement in some of the planning for this conference:

Actually, I had my daughter, my third child was born just three weeks before that and I remember sitting up in bed and [a colleague] came, she was working as a social worker, she was on the organising committee. I remember her coming in and sitting on my bed at National Women's allocating people rooms for the conference, so that conference I always remember rushing home to the baby all the time (J. Kendrick, personal correspondence, 10/11/1999).

These were interesting times for women. June describes a desire to return to work in Child Welfare once her children were a bit older, but that this was not an option open to her.

I'd loved to have gone back to child welfare but you see, even though I was known, and knew people, most of them just said, 'we can't have you' ... the then district child welfare officer at Auckland had very firm ideas that you couldn't possibly go around visiting people whose care of children you were going to question, if you yourself had left your children in the care of other people (J. Kendrick, personal correspondence, 10/11/1999).

June was an active member of the Social Work Association and sat on various sub-committees including the Education and Training Committee. While able to work part time June relates that the Association also provided back to her. 'I think in a way I looked upon the Social Worker's Association as saving me from suburban neurosis. It offered me that sort of outlet, shall we say' (J. Kendrick, personal correspondence, 28/07/06).

June continued her contribution to the Association throughout her career. She sat on the committee to set up the standards for competency assessment in 1990-1991 and also acted as 
a national competency assessor for the Association in its early days. Because of June's links to history and policy she was able to contribute to the Association's advocacy functions:

She has been well able to see the needs of the individual/family in the wider context of society and its social policies, or lack of, or their inadequacies. It was in this latter activity that she saw the role of an Association of Social Workers that could comment on or even advise the Government of the day. And it did so in its first 25-30 years (J. MacKenzie, personal correspondence, $7 / 12 / 2011$ ).

\section{Back to education}

In 1968 June had the opportunity to go back to teaching and returned to work at Baradene College on a part-time basis. She became head of the history and social studies department. She also began lecturing in the evenings within the Certificate of Social Services at the University Extension. She taught papers in the history of social work and social work services for several years. By 1975 June was the deputy principal at Baradene and felt herself at a crossroads in terms of her career. In the end, she decided that she wanted to return to social work and went back to Auckland Hospital as supervising social worker for two years.

\section{The Auckland MA programme}

The process of development of social work education in Aotearoa New Zealand was initially a slow and painful one. In 1976, in addition to the programme at Victoria, social work programmes were established at Massey University in Palmerston North and at Canterbury University, but there was still nothing available in the Auckland region. In 1981, the Rochford and Robb research working party, which included Tom Austin, Ms Bruce, Ephra Garrett, June Kendrick, Mr Lucas and Dugald McDonald published its report, 'People in the Social Services'. It reported that $78 \%$ of social workers were unqualified and that, 'Considering the complexity of cases carried by social workers, the responsibility attached to them and the long-term effect of their intervention in their clients' lives, such a gap in training is quite unacceptable' (Rochford and Robb, 1981, p. 4).

This is an important point and is one that is in tune with the current culture of accountability. People in the Social Services was the most comprehensive survey of the social service workforce available and provided the only national survey relating to all known social services in New Zealand.

In the same year as the Rochford and Robb report was published, the University Grants Committee Review Committee for Social Work, known as the Brownlie Report, came out in favour of situating social work courses in university settings, though some universities were more willing to host programmes for the education of social workers than others. Auckland University had certainly shown little interest in developing a programme, but David Pitt, within the Sociology Department was interested in supporting the development of social work training within the University. June observes that:

There was never ever any great enthusiasm in the University itself and perhaps at the higher levels ... there was quite a lot of opposition too ... even from the Sociology Department, for having what they saw as being a vocational course coming into the rarified atmosphere of the university (J. Kendrick, personal correspondence, 28/07/06). 
Brian Manchester recalls a conversation with one professor at the University:

On one occasion I had asked Professor XXXXXX why what I understood was to be a social work practitioner course had been given such a vague title as 'Master of Social Welfare and Development'. His response was 'because social work is regarded as somewhat disreputable amongst my academic colleagues' (B. Manchester, personal correspondence, 06/02/06).

In 1977, with a three-year grant provided by Mobil Oil, June was hired to establish the MA Sociology (Social Work and Social Administration or Social Welfare). This was a two-year programme for people already holding undergraduate degrees and was made up of a combination of papers, practical work and a thesis. June describes the cohort of the programme:

I think essentially it was a good course and we've had some very, very good people come through the course ... we actually had three intakes and it was again a good group because they were all postgraduates, they all had prior degrees, but there was a variety of people, never a big number, but they grew, I suppose, up to about 14 or something like that, who completed the degree (J. Kendrick, personal correspondence, 28/07/06).

Pitt had hoped that through this three-year period the programme would eventually gain the support of the University, but this did not occur. Pitt left the Sociology Department in 1979 to take up a position with the World Health Organisation, but there was no mandate from the University to continue the programme after the three years of funding ended. June stayed on for a short period in order to enable students to complete their degrees.

By this time, June had begun work on her $\mathrm{PhD}$, where she hoped to look at the operation of what had previously been the Child Welfare Department. Professor Pitt had been her supervisor and with his departure, June moved over to the History Department under the direction of Keith Sinclair. She continued this for a time while working back at Carrington Hospital. Eventually she decided to discontinue her $\mathrm{PhD}$ and it was not long before she was called back into full-time social work practice.

\section{The Residential Care Team and social policy}

In the early 80s, social workers within the Auckland Health Board had become increasingly concerned about some of the psychiatric and geriatric placements in rest homes for patients being discharged from institutions. This corresponded to deinstitutionalisation and the beginning of neo-liberal reforms and privatisation of care in New Zealand. Social workers within the Auckland Hospital Board rallied and advocated for the appointment of a team to monitor nursing homes. In 1982, June was appointed to lead the Residential Care Team, a regional Auckland Area Health Board service with two other appointed staff. They were also supported by staff from the other hospitals who discussed possible placements with the team. In helping June to sort her archives, it became clear that in this new position, she had put her heart and soul into raising the standards of residential care for older people. Her archives contain many papers pertaining to her work informing and advising the Auckland Hospital Board, including a submission to the Royal Commission on Social Policy (1987). In the submission she describes how:

The Residential Care Team visits all Rest Homes in the greater Auckland area, and keeps a watching brief on the care being given to ex-patients of the Board's hospitals (including psy- 
chiatric) and to residents receiving rest home subsidies from the Department of Social Welfare ... The Team is consulted by Hospital Board social workers, relatives of patients, Rest Home residents and Home management and owners (Kendrick, 1987).

June related that her team was not always popular with providers and other health professionals. Providers found themselves under a degree of scrutiny which they had not previously experienced, while other nurses and social workers found themselves under intense pressure to empty beds into the community and the Residential Care Team was sometimes seen as a further obstacle to quick discharge.

Judith MacKenzie, a long-term friend and colleague of June's comments on June's contribution:

Awareness of the plight of older people, chattels in a growing industry of private residential
homes, she and her small team brought to light an appalling system. June's was a very strong
voice detailing neglect and the extent to which the state was subsidising supposed care. The
work of her team lead to the Department of Health eventually setting up a system for assess-
ment to residential care and close monitoring of the subsidies Government paid (J. MacKenzie,
personal correspondence, $7 / 12 / 2011$ ).

June was Sue Hanna's social work supervisor in the residential care team from 1982-1985. Sue Hanna describes how:

As a supervisor June was very supportive, both she and Judy Mackenzie had a significant influence on me as a young social worker. They were very committed to ideals of social justice but also put a great deal of emphasis on advocacy, relationship building and working in partnership with individual service users. In many ways they were overtaken by the divisiveness of the 80 s but their enduring emphasis on professionalization and accountability was something I remember about both of them. They fought the good fight for the rights of elderly people and have continued to do so in various ways over the years. Not many of us can claim to have walked the professional talk in the way they have (S. Hanna, personal correspondence, 04/03/2011).

June remained committed to the wellbeing of older people in various ways. She was the editor of the Age Concern newspaper which was distributed throughtout New Zealand and was made a life member of Auckland Age. June was also supportive of the University of the Third Age in New Zealand and continues to attend functions when possible.

\section{Discussion}

Terms used to express tensions and contradictions between the controlling and empowering aspects of social work may date, but every generation has experienced the same difficulty. Distinctions are drawn between social control, social care and social justice, casework and community work, remedial, preventive and developmental approaches (Benn, 1976). The client may either be helped to adapt to circumstances, or the social worker may attempt to bring about social change or social action on the client's behalf (Middleman and Goldberg, 1974), or with the client, using empowering and conscientising methods as advocated by Freire in 1972. The individual social worker will tend to focus either on civil rights, human rights, poverty, homelessness, discrimination and other structural inequalities, or on personal distress, crises, emotional trauma, family breakdown, abuse, and use their knowledge 
and skills to effect beneficial change, macro or micro (Ehrenreich, 1985 cited in Nash, 1998, p.56). June has always been well aware of these different approaches to social justice. Her understanding in this sphere has contributed strongly to her recognition as a Life Member of the ANZASW.

Her social work career spanned several decades in which New Zealand society changed greatly and political shifts altered the civic landscape almost beyond recognition. Through these times, June has demonstrated the importance of social policy, advocacy and social justice in social work practice. Setting up the Auckland end of the ANZASW, lecturing at Auckland university, working for the older person and residential care, presenting papers at conferences both here and internationally as well as publishing, are all examples of how she implemented her concern for social change and social justice. Her active involvement in social policy, being constantly involved in working parties and making submissions, provides a significant role model for today's social workers that demonstrates that this kind of work is part of what is meant by striving for social justice as a social worker.

In reviewing her life as a social worker, June's commitment and determination to make a difference are recognised by another social worker, Gavin Rennie, who wrote to us saying:

What struck me about June was this was a woman who brought to social work a myriad of gifts. She had a Masters in History, had occupied senior positions in secondary schools and was strongly committed to professional training as a sine qua non for social workers. Her training as a historian enabled her to take the long view on issues that were prevalent at the time and yet alongside that she appreciated the importance of understanding context (G. Rennie, personal correspondence, 25/01/2011).

In a reflective piece of writing: 'From social work to the other side of the fence' (2002) June echoes the theme of social work and gifts, when she observes that for her 'social work has offered what I now see as one of the greatest gifts one can receive - the opportunity to work with so many people who have become life-long friends' (J. Kendrick, unpublished source).

\section{Conclusion}

This article has attempted to present some of the contributions that June Kendrick has made to social work, social work education and social policy and adminstration over a 50-year period. June has demonstrated an ability to make a difference at many levels and in a variety of ways.

June recalls her time in social work with fondness and enthusiasm:

There was never a dull moment in social work. It was always exciting to go to work every day as you never knew what was going to turn up. There was always something new to be learned and no situation was ever fixed or static.

I think the most satisfying aspect of the job was knowing that I had done something to improve a situation ... that I had made a positive contribution.

I think I was a good social worker.

(J. Kendrick, personal correspondence, 27 / 01/2011). 


\section{References}

Benn, C. (1976). A new developmental approach for social work. In P. Boas \& J. Crawley (Eds). Social work in Australia. Melbourne, Vic, Australia: International Press and Pty Ltd.

Biestek, F. P. (1957). The casework relationship. Chicago, IL: Loyola University Press.

Biestek, F. P., \& Gehrig, C. (1978). Client self-determination in social work: A fifty year history. Chicago, IL: Loyola University Press.

Ehrenreich, J.H. (1985). The altruistic imagination. A history of social work and social policy in the United States. Ithaca, NY: Cornell University Press.

Freire, P. (1972). Pedagogy of the oppressed. (Translated by M.B.Ramos). Harmondsworth, England: Penguin.

Kendrick, J. (1987). Submission to the Royal Commission on Social Policy. Unpublished source.

Manchester, B. (2008). A perspective on welfare. Notes on a social work and public service career in child care and protection with the young offender, 1954-1987. Unpublished manuscript.

McCreary, J. (1971a). The school of science: Part one - The martians. The New Zealand Social Worker, 7(1), 9-17.

McCreary, J. (1971b). The school of science: Part two - The minions. The New Zealand Social Worker, 7(2), 41-50.

Middleman, R. \& Goldberg, G. (1974). Social service delivery: A structural approach to social work practice. New York, NY: Columbia University Press.

Nash, M. (1998). People, policies and practice. Social work education in Aotearoa/New Zealand from 1949-1995. Unpublished doctoral dissertation. Massey University, Palmerston North, New Zealand.

Rochford, M.W. \& Robb, M.J. (1981). People in the social services. A New Zealand survey. Wellington, New Zealand: New Zealand Social Work Training Council.

University Review Committee Working Party. (1981). Report on social work education in universities, (Brownlie Report). Wellington, New Zealand: Review Committee of the University Grants Commitee. 